\title{
Persepsi Sosial Terhadap Komodifikasi Tubuh Perempuan (Studi Kasus Sales Promotion Girl Di Mall Ratu Indah Makassar)
}

\author{
${ }^{1} \mathrm{Rusni} \mathrm{Hadji}$ \\ Universitas Muhammadiyah Makassar - Indonesia \\ ${ }^{2}$ Drs. H.Nurdin, M.Pd \\ Universitas Muhammadiyah Makassar - Indonesia \\ ${ }^{3}$ Lukman Ismail \\ Universitas Muhammadiyah Makassar - Indonesia \\ Email : lukmanismail@unismuh.ac.id
}

\begin{abstract}
Public spaces such as malls and entertainment venues have been visited by many people. This opportunity is used by industries engaged in the service sector to make a profit. Not a few agencies have created jobs to recruit employees in the field of promotional services. Promotion services work in the informal sector with the skills required by agencies to recruit women as sales promotions. SPG is used as a shortcut for some women to get a job. Women have a gentle attitude and are good at seducing with their physical capital, beautiful faces and eloquence in offering products to customers. SPG is used as the main job for women to make it easier to earn money. Most of the women who only go to school until they finish Senior High School (SMA) or Vocational High School (SMK) choose to work as SPGs. This job does not require high skills, only with a beautiful physique and face. This gives the view that the body and face are working capital as an SPG. The company benefits more from the SPG because it is seen as being able to boost product sales. In this study, the type of research used is a qualitative approach, namely "a research procedure that produces descriptive data in the form of writing and behavior that can be observed from the subject itself. The results of this study are 1) The concept of the body as a commodity is a common symptom in Makassar City. The body is likened to a commodity that has a selling value. As a commodity, the body can be converted just as the concept of the body is physical capital which can be converted into economic, cultural and social capital; 2) Some people view the SPG profession as a negative profession. because seen from the symbols attached to the SPG, for example, from wearing sexy clothes, make-up, to more aggressive and coercive verbal language when offering products and also the profession of SPG is a profession that only relies on beauty; 3) Negative stereotypes have been embedded in some societies so that what the general public perceives about SPG is almost the same.
\end{abstract}

Keywords : Social Perception; Body Commodification; SPG.

\begin{abstract}
Abstrak
Ruang publik seperti Mall dan tempat-tempat hiburan banyak didatangi masyarakat. Peluang ini dimanfaatkan oleh industri yang bergerak pada bidang jasa untuk mendapatkan keuntungan. Tak sedikit agency yang membuka lapangan kerja untuk merekrut karyawan dalam bidang jasa promosi. Jasa promosi bekerja pada sektor informal dengan keahlihan yang dibutuhkan agensi merekrut perempuan sebagai sales promotion. SPG dijadikan jalan pintas bagi sebagian perempuan untuk mendapatkan pekerjaan. Perempuan memiliki sikap yang lembut dan pandai merayu dengan bermodalkan fisik, wajah cantik serta kepandaian berbicara dalam menawarkan produk kepada pelanggan. SPG dijadikan sebagai pekerjaan utama bagi perempuan untuk mempermudah mendapatkan uang. Sebagian besar perempuan yang hanya menempuh sekolah hingga tamat Sekolah Menengah Atas (SMA) atau Sekolah Menengah Kejurusan (SMK) memilih untuk bekerja sebagai SPG. Pekerjaan ini tidak membutuhkan skill yang tinggi, cukup bermodalkan fisik dan paras yang cantik. Hal ini memberikan pandangan bahwasannya tubuh dan paras menjadi modal bekerja sebagai SPG. Perusahaan lebih diuntungkan dengan adanya SPG karena dipandang mampu mendongkrak penjualan produk. Dalam penelitian ini jenis penelitian yang digunakan adalah pendekatan kualitatif yaitu "suatu prosedur penelitian yang menghasilkan data deskriptif berupa tulisan dan perilaku yang
\end{abstract}


dapat diamati dari subyek itu sendiri. Adapun hasil penelitian ini adalah 1) Konsep tubuh sebagai komoditas merupakan gejala yang umum ditemui di Kota Makassar. Tubuh diumpamakan sebagai salah satu komoditas yang memiliki nilai jual. Sebagai komoditas, tubuh dapat dikonversikan seperti konsep tubuh adalah modal fisik yang dapat dikonversikan menjadi modal ekonomi, budaya dan sosial ; 2) Sebagian masyarakat memandang profesi SPG adalah salah satu profesi yang negatif. karena dilihat dari simbol-simbol yang melekat pada SPG misalnya dari penggunaaan baju yang seksi, make up, sampai kepada bahasa verbal yang lebih agresif dan memaksa pada saat menawarkan produk dan juga profesi SPG adalah salah satu profesi yang hanya mengandalkan kecantikan; 3) Streotip yang negatif sudah tertanam di sebagian masyarakat sehingga apa yang dipersepsikan oleh masyarakat umum terhadap SPG hampirsama.

Kata Kunci : Persepsi Sosial; Komodifikasi Tubuh; SPG. 


\section{PENDAHULUAN}

Kebutuhan adalah sesuatu yang harus tercukupi bagi makhluk hidup untuk melangsungkan hidupnya, sebagai tujuan untuk bertahan hidup kebutuhan manusia wajib dipenuhi dan harus ada. Setiap orang memiliki kebutuhan hidupnya sendiri dan berbeda-beda, perbedaan kebutuhan manusia itu dipengaruhi oleh banyak faktor salah satunya adalah faktor ekonomi. Untuk memenuhi kebutuhan tersebut setiap orang memerlukan pekerjaan. Peranan pekerjaan sangatlah besar dalam memenuhi kebutuhan hidup sehari-hari, terutama kebutuhan ekonomis, sosial, dan psikologis.

Secara ekonomis, orang yang bekerja akan memperoleh penghasilan atau uang yang bisa digunakan untuk membeli barang dan jasa guna mencukupi kebutuhan hidup seharihari. Secara sosial orang yang memiliki pekerjaan akan lebih dihargai oleh masyarakat dari pada orang yang menganggur. Orang yang bekerja akan mendapat status sosial yang lebih terhormat daripada yang tidak bekerja. Lebih jauh lagi, orang yang memiliki pekerjaan secara psikologis akan meningkatkan harga diri dan kompetensi diri. Pekerjaan juga dapat menjadi wahana untuk mengaktualisasikan segala potensi yang dimiliki individu.

Dewasa ini terjadi perubahan paradigma pada perempuan menyangkut peran yang disandangnya dalam masyarakat. Perempuan kini tidak lagi memegang peran tunggal, namun mengembangkan peran ganda. Hal ini terjadi karena perubahan peran perempuan yang semula hanya bekerja di sektor domestik mulai merambah juga ke sektor publik sehingga menyebabkan perubahan struktur sosial yang memberi bentuk baru pada peranan perempuan dalam keluarga dan masyarakat. Pekerjaan perempuan di sektor publik pun tersedia dalam berbagai bidang. Walaupun demikian sebagian besar profesi yang tersedia untuk perempuan masih berkisar pada pekerjaan yang kurang memiliki prestise dan tuntutan ketrampilan khusus. Pekerjaan perempuan sebagai SPG merupakan salah satu contoh.

Profesi ini lekat dengan kesan hanya mengandalkan modal fisik semata. Dengan alasan tuntutan pekerjaan, tidak jarang mereka terpaksa harus menampilkan diri dengan pakaian minim dan dandanan menor untuk menarik banyak pembeli dari pangsa pasar. Menurut (Syamsudin,2006: 2) Perempuan memang diciptakan indah, cantik dan mempesona. Kesempatan ini tidak dilepaskan oleh kaum kapitalis bagi pengembangan usaha mereka. Wanita dan dunia usaha atau bisnis adalah dua hal yang sulit dipisahkan.

Kapitalisme melalui budaya komoditasnya menjadi media utama tubuh untuk revolusi dan melepaskan hasrat serta kebebasannya. Kapitalisme, di satu sisi, menolong tubuh dengan cara membebaskan dari berbagai macam kekangan dan aturan. Dan di sisi lain mengeksploitasi potensi hasrat dan libido yang dimilikinya untuk dikomersialisasikan. Ketika terbebas dari segala macam kekangan, norma, tabu dan nilai moral, tubuh menjadi bersifat material dan sekuler. Ketika tubuh tanpa kendali otoritas kekuasaan (keluarga, Negara, agama) dan hanya dikendalikan prinsip kapital, terciptalah yang oleh Baudlirrad disebut sebagai budaya ketelanjangan (obscene culture). Sebuah budaya tubuh yang tanpa rahasia dan tanpa tabir, yang dapat dieksplorasi segala potensi dan kekuatan libidonya untuk kepentingan kapital.

Terdapat tiga persoalan yang menyangkut eksistensi perempuan di dalam wacana ekonomi-politik 
khususnya dalam dunia komoditi. Pertama, persoalan ekonomi politik tubuh yaitu bagaimana aktivitas tubuh perempuan digunakan dalam berbagai aktivitas ekonomi, berdasarkan pada konstruksi sosial atau ideologi tertentu. Kedua, persoalan ekonomi politik tanda yaitu bagaimana perempuan diproduksi sebagai tanda-tanda di dalam sebuah sistem pertandaan khususnya di dalam masyarakat kapitalis yang membentuk citra makna dan identitas (identity) diri mereka di dalamnya. Ketiga, persoalan ekonomi politik hasrat yaitu bagaimana hasrat perempuan disalurkan atau direpresi di dalam berbagai bentuk komoditi, khususnya komoditi hiburan dan tontonan (Piliang, 2003). Persoalan ekonomi politik tubuh berkaitan dengan sejauh mana eksistensi perempuan di dalam kegiatan ekonomi politik, khususnya dalam proses produksi komoditi.

Persoalan ekonomi politik tanda berkaitan dengan eksistensi perempuan sebagai citra di dalam berbagai media (televisi, film, video, musik, majalah, koran, komik, seni lukis, dan fashion). Sementara ekonomi politik hasrat berkaitan dengan bagaimana tubuh dan citra berkaitan dengan pembebasan dan represi hasrat. Yang pertama, melukiskan eksistensi perempuan dalam dunia fisik. Kedua di dalam dunia citra dan yang ketiga, di dalam dunia psikis . Meskipun ketiga dunia tersebut saling berkaitan satu-sama lainnya (Piliang, 2003). Penggunaan tubuh dan representasi tubuh sebagai komoditi (komodifikasi) di dalam berbagai media hiburan maupun perdagangan masyarakat kapitalis, telah mengangkat berbagai persoalan yang tidak saja menyangkut relasi ekonomi (peran ekonomi perempuan), akan tetapi lebih jauh relasi ideologi yaitu bagaimana penggunaan tubuh dan citra tersebut menandakan sebuah relasi social khususnya relasi gender yang dikonstruksi berdasarkan sistem ideologitertentu.

Ruang publik seperti Mall dan tempat-tempat hiburan banyak didatangi masyarakat. Peluang ini dimanfaatkan oleh industri yang bergerak pada bidang jasa untuk mendapatkan keuntungan. Tak sedikit agency yang membuka lapangan kerja untuk merekrut karyawan dalam bidang jasa promosi. Jasa promosi bekerja pada sektor informal dengan keahlihan yang dibutuhkan agensi merekrut perempuan sebagai sales promotion. SPG dijadikan jalan pintas bagi sebagian perempuan untuk mendapatkan pekerjaan. Perempuan memiliki sikap yang lembut dan pandai merayu dengan bermodalkan fisik, wajah cantik serta kepandaian berbicara dalam menawarkan produk kepada pelanggan.

Profesi ini lebih tepat ditujukan kepada perempuan, karena pekerjaan ini sesuai dengan bidang perempuan yang dapat menciptakan feminitas. Secara umum tugas SPG adalah mempromosikan dan menjual produk kepada pelanggan dengan sebaikbaiknya. Ada anggapan bahwa "pembeli adalah raja" karena itu dibutuhkan kesabaran, ketelatenan serta keramahan dalam melayani customer. Peran ini mengingatkan pada pekerjaan sektor domestik yang sering kali dihubungkan dengan sifat dasar perempuan pada umumnya, yakni sabar, telaten, halus, lembut dan perayu. Perilaku dalam pekerjaan ini akan menentukan suasana penjualan, sedangkan ucapan dapat mempengaruhi keputusan pelanggan.

SPG menjadi titik utama penjualan dengan penempatan di depan. Hal tersebut dikarenakan dapat dilihat dari sudut pandang depan dan mampu menarik perhatian masyarakat di sekitar. Secara sengaja para pengusaha memerankan posisi SPG untuk dijadikan sebagai nilai jual atau selling point bagi produk tersebut dengan memanfaatkan tubuh perempuan, sehingga perusahaan 
mendapatkan keuntungan yang besar. Penempatan SPG pada lokasi yang ramai dan banyak dikunjungi masyarakat seolah menjadi sebuah kewajiban. Hal tersebut dilakukan karena memberikan peluang besar produk dapat terjual lebih banyak. Pekerjaan ini lebih banyak dipilih perempuan dikarenakan penghasilan gaji yang besar dan tidak menggeluarkan banyak tenaga. Para pekerja wajib menggunakan seragam yang telah diberikan oleh perusahaan. Seragam pada pekerjaan ini cenderung seksi dan terbuka agar pelanggan tertarik untuk membeli. Secara sengaja perusahaan memberikan seragam yang seksi dan terbuka untuk menonjolkan lekuk tubuh agar menarik perhatian pelanggan. Penampilan menarik menjadi kriteria utama dalam pekerjaan ini. Penampilan adalah bentuk tubuh yang menarik untuk ditampilkan di depan umum. Peran SPG dalam mempromosikan produk memiliki kedudukan yang penting karena berpengaruh dalam penjualan produk.

Pada saat ini kebutuhan sebuah perusahaan akan SPG tergantung dari brand atau produk yang akan di promosikan, misalnya produk otomotif, dalam sebuah pameran mobil sudah sangat identik sekali akan hadirnya sosok SPG. Tetapi semakin meningkatnya persaingan atau kompetisi bisnis pada saat ini membuat hampir sebagian besar produk memilih menggunakan jasa SPG sebagai salah satu strategi pemasaran yang sangat efektif tidak terkecuali mall ratu indah yang terletak di kota makassar.

\section{KOMODIFIKASI TUBUH PEREMPUAN}

Komodifikasi menggambarkan proses dimana sesuatu tidak yang memiliki nilai ekonomis diberikan nilai dan karenanya bagaimana pasar dapat menggantikan nilai-nilai sosial lainnya
(Evan,2004 :16). Komodifikasi adalah transformasi barang, jasa, gagasan dan orang dalam komoditas, atau barang dagang. Menurut Arjun Appadurai komoditas pada bagian paling dasarnya adalah hal apapun yang dapat ditukar atau barang apapun yang memilki nilai ekonomi (Wikipedia)

Komodifikasi menurut Mosco (2009:127) dalam Hidayat, T.W. (2016) merupakan proses transformasi atas sesuatu yang dianggap bernilai untuk dijadikan produk yang dapat dijual. Proses tersebut merupakan cara kapitalisme melancarkan tujuannya untuk mengakumulasi modal dengan mentransformasikan nilai guna menjadi nilai tukar.

Komodifikasi merupakan istilah baru yang mulai muncul dan dikenal oleh para ilmuan sosial. Komodifikasi mendeskripsikan cara kapitalisme melancarkan tujuannya dengan mengakumulasi kapital, atau menyadari transformasi nilai guna menjadi nilai tukar. Komoditas dan komodifikasi adalah dua hal yang memiliki hubungan obyek dan proses, dan menjadi salah satu indikator kapitalisme global yang kini tengah terjadi. Komodifikasi merupakan bentuk transformasi dari hubungan, yang awalnya terbebas dari hal-hal yang sifatnya diperdagangkan, menjadi hubungan yang sifatnya komersil.

Secara teoritik, komodifikasi menjelaskan cara kapitalis dalam menjaga suatu tujuan untuk mengakumulasi kapital atau merealisasi nilai melalui transformasi nilai guna kepada nilai tukar. Komodifikasi seringkali diikuti dengan membedakan kedangkalan dan manipulasi komoditas kebudayaan otentik masyarakat (Marx, 1977). Dalam Al-hadi,R.A \& Hidayat (2017).

Konsep tubuh sebagai komoditas merupakan gejala yang umum ditemui 
dalam budaya konsumen. Tubuh diumpamakan sebagai salah satu komoditas yang memiliki nilai jual. Sebagai komoditas, tubuh dapat dikonversikan seperti konsep tubuh adalah modal fisik yang dapat dikonversikan menjadi modal ekonomi, budaya dan sosial. Tubuh yang berhias diumpamakan sebagai komoditas yang dapat meningkat nilai jualnya. Komoditas yang menghias tubuh secara sendirinya juga harus mencitrakan diri si pemakai, mengenai selera dan gaya hidupnya. Secara bersama-sama, tubuh dan pembungkusnya dilihat sebagai satu paket yang saling mentransfer nilai. Dalam budaya konsumen, tubuh tidak terikat pada kelas tertentu seseorang dilahirkan tetapi lebih pada kemampuaanya mengkonsumsi, sehingga seseorang mencitrakan nilai murah atau mahal sesuai dengan yang dikonsumsinya.

Tubuh memiliki kebebasan relative di dalam ruang pribadi. Sebaliknya ketakbebasan relative dalam ruang publik, karena disini tubuh harus tunduk pada aturan-aturan social. Dengan perkataan lain, tubuh memainkan dua peran yang terkadang bersifat kontradiktif yaitu peran personal dan social. Hal ini sesuai dengan posisi perempuan yang bekerja sebagai SPG ketika ia ada dalam dunia kerjanya maka peran social yang tampilkan ia menjadi sasaran dari berbagai aturan, batasan, kendala, halhal lain yang bersifat memaksa. Persoalan ekonomi berkaitan dengan sejauh mana eksistensi tubuh perempuan di dalamnya, khususnya di dalam proses produksi komoditas. Ketika tubuh perempuan dijadikan komoditas maka segala potensi tubuh dieksploitasi sebagai cara menarik perhatian.

Fuocault menganalisis masalah seksualitas yang kemudian dikaitkan dengan kekuasaan. Modernisasi dengan globalisasi sebenarnya dibawah pengawasan kekuasaan atau yang dinamakan dengan relasi kekuasaan (Piliang:2006 dalam Nursalam dkk;2016). Relasi dominasi yang dimaksud adalah dominasi waktu dan ruang. Dalam wacana perkembangan politik, social dan budaya kapitalis global, kekuasaan juga berkembang melalui apa yang dinamakan kecepatan power, kecepatan memperoleh informasi, kecepatan mengatisipasi pasar, kecepatan menjawab, kecepatan mengejar trend.

Gagasan Foucault dapat digunakan dalam menganalisis masyarakat modern, tidak hanya batas-batas mengenai apa yang diperbincangkan, diperlihatkan, dipertontonkan, mengenai seks. Berbagai hal mengenai seks seperti kejahatan seksual dan lain-lain mulai di foto, difilimkan dan di pasarkan dijual dan dikomoditaskan. Sebaliknya apapun yang berada diluar seks kini diseksualitaskan seperti berbagai kampanye yang menghadirkan artisartis seksi, pameran motor, mobil, laptop, kulkas, televise dan lain-lain selalu menggunakan sales promotion girl.

Dalam system ekonomi libido, belahan dada yang terlihat transparan dalam acara fashion show, sebuah betis terbuka, sebuah paha yang diekspos dalam iklan, bukanlah bentuk degradasi moral, malainkan bentuk nilai jual yang amat berharga. Para penganut system ekonomi libido tidak lagi mengindahkan persoalan moral, agama, etika, ataupun undang-undang. Mereka hanya memikirkan bagaimana cara memperoleh berlipat-lipat keuntungan ekonomis. Tubuh hanyalah dianggap memiliki nilai keuntungan dan ekonomis bila dapat di produksi dan direproduksi sebagai nilai tukar lewat berbagai basaha tubuh dalam iklan atau pameran. Menurut Barthes, mekanisme kekerasan dalam iklan atau pameran itu dinamakan logo tehknik, yakni 
Bahasa buatan iklan demi menggoda selera konsumen melalui pertubuhan menjadikan tubuh memiliki makna merayu hasrat konsumtif manusia. (Barthes 1981 dalam Raditya; 2014). Nilai tanda tubuh perempuan sebagai komuditi yang didekontruksi iklan atau pameran dapat dilihat melalui beberapa aspek.

Pertama tampilan tubuh, dalam dunia iklan tampilan tubuh perempuan seolah menjadi menu yang tidak bisa ditinggalkan. Hamper kebanyakan iklan memanfaatkan tubuh perempuan sebagai media menawarkan produk, baik untuk kaum perempuan maupun laki-laki. Anehnya produk yang sebenarnya segmen pasarnya untuk kaum laki-laki pun selalu memanfaatkan perempuan sebagai media promosinya. Kedua perilaku, perilaku merupakan aspek lain yang menentukan relasi tanda tubuh di dalam iklan. Hal ini dapat dilihat dari eksperi tubuh dengan berbagai gaya yang cenderung berani.

Ketika perempuan disuruh tampil depan umum dengan pakaian yang seksi untuk mempromosikan suatu produk, maka pada saat itulah perempuan mengalami yang oleh Piere Bourdiu disebut sebagai kekerasan simbolik. Kekerasan simbolik adalah kekerasan yang secara paksa digunakan oleh pihak tertentu guna mendapatkan kepatuhan yang tidak dapat dirasakan sebagai paksaan yang bersandar pada harapanharapan kolektif dari kepercayaankepercayaan yang sudah tertanam secara social. Seperti halnya ilmu gaib kekerasan simbolik berdasarkan pada teori kepercayaan yang di dapatkan dari proses sosialisasi yang perlukan untuk memproduksi pelaku-pelaku social yang dilengkapi dengan skema persepsi dan apresiasi yang memungkinkan mereka mampu menerima perintah-perintah yang diberikan dalam suatu wacana dan mematuhinya. (Rusdiarti:2003 dalam Raditya:2014).
Kekerasan simbolik bekerja
melalui penyembunyian kekerasan sehingga kekerasan menjadi sesuatu yang diterima sebagai yang memang seharusnya demikian. Inilah yang oleh Piere Bourdiu disebut sebagai doxa. Karena itulah akhirnya perempuan merasa rela dan seolah-olah menyadari untuk memperlihatkan bagian-bagian tubuhnya dihadapan public. Padahal kondisi itu justru menyebabkan tubuh perempuan tereduksi nilai-nilai harkat dan martabat kemanusiaan karena tubuhnya bisa dinikmati oleh siapa saja, diumbar secara gratis. Tubuhnya digambarkan hanya sebatas obyekseksual dan bujuk rayu konsumsi. Anehnya kekerasan dalam bentuk pencitraan ini oleh kaum perempuan itu tidak dilihat sebagai kekerasan, tetapi sebagai sesuatu yang alamiah dan wajar, sesuatu yang eksotis dan estetis. Para perempuan mengggap hal itu sebagai tuntutan profesionalisme kerja yang harus dilakukannya.

\section{HASIL PENELITIAN DAN PEMBAHASAN}

Penampilan SPG yang menarik dianggap dapat membantu memperkenalkan suatu produk dan mengundang perhatian konsumen terhadap produk tersebut. Dengan kemampuan berkomunikasi yang baik, $\mathrm{S}$ PG yang berpenampilan menarik diharapkan dapat mempengaruhi konsumen untuk melakukan pembelian suatu produk. Profesi SPG yang umumnya lebih banyak dilakukan oleh perempuan muda, mulai menjadi pekerjaan yang semakin umum di masyarakat tidak terkecuali Kota Makassar. Pekerjaan sebagai SPG nampaknya memiliki daya tarik tersendiri bagi banyak perempuan muda, antara lain karena tidak menuntut tingkat pendidikan yang tinggi tetapi imbalan finansial besar. 
Namun profesi SPG ini juga rentan terhadap berbagai isu-isu negatif. Pakaian sexy dan minim, riasan yang mencolok, dan sikap yang centil dari sebagian SPG ketika berusaha menarik perhatian konsumen telah melahirkan persepsi negatif di masyarakat terhadap profesi ini. SPG dinilai hanya mengandalkan kemolekan tubuh dan riasan wajah saja tanpa didasari oleh pendidikan yang tinggi atau keahlian. Dengan kata lain, dapat dikatakan bahwa profesi ini secara umum masih dipandang rendah oleh masyarakat, dan dianggap sebagai profesi yang "kurang baik." anggapan dan prasangka negatif masyarakat akan profesi SPG ini seakan telah menjadi stereotype negatif yang mengabaikan adanya tuntutan profesionalitas dalam profesi tersebut.

Menurut Kreitner dan Kinick dalam Hendi dan Anggara (2010:185) persepsi adalah merupakan proses kognitif yang memungkinkan kita menginterpretasikan dan memahami sekitar kita. Dikatakan pula sebagai proses menginterpretasikan suatu lingkungan. Orang harus mengenal objek untuk berinteraksi sepenuhnya dengan lingkungan mereka. Pada hakikatnya persepsi merupakan suatu proses yang memungkinkan kita mengorganisir informasi dan menginterpretasikan kesan terhadap lingkungan sekitarnya. Seseorang apabila melihat objek atau orang lain dapat mempunyai kesan yang berbeda dibandingkan dengan orang lainnya. Demikian pula, pandangan seseorang dapat berubah apabila lingkungan berubah dan kesan seseorang dipengaruhi oleh informasi yang dimiliki.

Terbentuknya persepsi setiap individu itu tergantung bagaimana melihat suasana maupun keadaan yang ada di sekitar individu tersebut. Hal ini sesuai dengan pernyataan salah satu informan Pak IN dengan berbahasa atau logat makassar, (30 Tahun) ia berpendapat terkait dengan penampilan fisik, body language.

"Kalo kita liat spg kita mulai liat fashioannya dia, fash dulu, mukanya dulu, apakah mempunyai daya pikat untuk bagaimana kita mendekati dia kemudian stylenya dia bagaimana kalo untuk sales walaupun penjualannya bagus kalo kita liat saja tdk mau yah pastimi penjualannya tidak bagus. Menurutku begitu memang SPG kalo mauki menarik pembeli haruski cantik, berpakaian yang bagus karena itumi yang bikin penjualan meningkat seperti yang saya bilang tadi kalo dia diliati saja ndak mau yah saya juga tidak mauka juga beli disitu."

Dari pendapat informan diatas dapat disimpulkan bahwa seorang SPG memang harus cantik dan berpenampilan menarik karena dengan begitu bisa menarik pembeli dan meningkatkan penjualan karena menurutnya yang pertama kali diliat oleh calon pembeli adalah SPG-nya jika SPG-nya tidak mau dipandang sama calon pembeli maupun pengunjung maka bisa berpengaruh terhadap calon pembeli maupun pengunjung yang secara tidak langsung dapat menurunkan penjualan mereka atau yang sering disebut dengan perilaku konsumen. Perilaku konsumen adalah proses seorang pelanggan dalam membuat keputusan untuk membeli, menggunakan serta mengkonsumsi barang-barang dan jasa yang dibeli, juga termasuk faktor-faktor yang mempengaruhi keputusan pembelian dan penggunaan produk. Perilaku konsumen dapat diartikan sebagai studi tentang proses pengambilan keputusan oleh konsumen dalam memilih, membeli, memakai serta memanfaatkan produk, jasa, gagasan, atau pengalaman dalam 
rangka memuaskan kebutuhan dan hasrat konsumen.

Persepsi adalah merupakan proses menerima informasi membuat pengertian tentang dunia di sekitar kita. Hal tersebut memerlukan pertimbangan informasi mana perlu diperhatikan, bagaimana mengkategorikan informasi, dan bagaimana menginterpretasikannya dalam kerangka kerja pengetahuan kita yang telah ada. (McShane dan Von Glinow, dalam Hendi dan Anggara 2010:68).

Persepsi masyarakat terhadap pekerjaan atau profesi sales promotion girl (SPG), sebetulnya cukup bervariasi atau berbeda-beda. Tidak semua orang memberikan komentar negatif, ada juga yang memberikan opini yang positif. Sebagai contoh ada penilaian dalam persepsi masyarakat yang pertama dalam hal negatif seperti berpakaian sexy dalam bekerja lebih menonjolkan bentuk fisik tubuh, make up yang berlebihan dan dengan gaya bicara lemah gemulai atau menggoda. Dalam pandangan masyarakat keberadaan SPG atau sejenisnya yang umumnya berpakaian sexy acap kali dicitrakan negatif, hal seperti ini sering terjadi walaupun sebagian besar tidak semua SPG demikian, maka hal tersebut yang membuat opini masyarakat menjadi negatif. Dan yang kedua adalah penilaian yang positif seperti membantu konsumen dalam menginformasikan kualitas produk tersebut sampai dengan cara perawatannya, dan membantu memilihkan barang yang sesuai dengan kebutuhan dan apa yang diinginkan oleh konsumen.

Berbeda hal yang disampaikan oleh NM, (21 Tahun) ia berpandangan bahwa

"Kitakan banyak mayoritas islam maunya toh saling menghargailah kalo memang di tempat umum jangan berpakaian yang terlalu seksi begitu. Kan begini kalo misalnya diliat dari segi sosialnya begini pastikan ada juga orang yang risikan orang ini harus saling tau menaulah maksudnya kita harus saling peduli kalo misalnya ini memang membuat ketidaknyamanan sama orang lain, lebih banyak dampak negatifnya mending jangan walaupun itu tuntutan dari kantor seharusnya memang harus diperbaiki dari atasannya maksudnya seharusnya di Indonesia ndak ada peraturan kayak begini terutama untuk spg. Itu juga yang sales mungkin mereka berpikir dengan untuk menarik perhatian laki-laki yang lawan jenisnya mau singgah disitu hanya sekedar untuk liatliat siapa tau tertarik".

Berdasarkan hasil wawancara diatas maka dapat disimpulkan bahwa masyarakat Kota Makassar mayoritasnya beragama islam yang harus saling menghargai dalam cara berpakaian apalagi mall merupakan tempat umum karena tidak semua orang memandang hal tersebut baik dan merasa nyaman. Menurutnya sebaiknya tidak perlu perempuan berpakaian seperti itu karena bisa mengundang halhal yang tidak diinginkan Walaupun itu tuntutan pekerjaan dan juga menurutnya seharusnya di Indonesia tidak perlu ada aturan pekerjaan seperti itu apalagi untuk profesi seperti SPG yang kerjanya di tempat umum. Akan tetapi menurutnya seorang SPG berpakaian seperti itu untuk menarik perhatian laki-laki sehingga para pengunjung yang datang selain membeli mereka juga memperhatikan para perempuan tersebut. 


\section{KESIMPULAN}

Dari hasil penelitian yang di lakukan di mall ratu tentang persepsi social terhadap komodifikasi tubuh perempuan dapat disimpulkan bahwa:

1. Konsep tubuh sebagai komoditas merupakan gejala yang umum ditemui di Kota Makassar. Tubuh diumpamakan sebagai salah satu komoditas yang memiliki nilai jual. Sebagai komoditas, tubuh dapat dikonversikan seperti konsep tubuh adalah modal fisik yang dapat dikonversikan menjadi modal ekonomi, budaya dan sosial. Tubuh yang berhias diumpamakan sebagai komoditas yang dapat meningkat nilai jualnya.

2. Sebagian masyarakat memandang profesi SPG adalah salah satu profesi yang negatif. Karena dilihat dari simbol-simbol yang melekat pada SPG misalnya dari penggunaaan baju yang seksi, make up, sampai kepada bahasa verbal yang lebih agresif dan memaksa pada saat menawarkan produk dan juga profesi SPG adalah salah satu profesi yang hanya mengandalkan kecantikan.

3. Respon dari SPG tentang profesinya adalah biasa-biasa saja sama seperti profesi lain karena setiap pekerjaan ada aturan masing-masing yang harus taati oleh pekerjanya.

4. Streotip yang negatif sudah tertanam di sebagian masyarakat sehingga apa yang dipersepsikan oleh masyarakat umum terhadap SPG hampir sama.

\section{DAFTAR PUSTAKA}

Al-hadi,R.A \& Hidayat (2017). Komodifikasi Tubuh Perempuan di Instagram (Analisis Wacana pada Endorser Perempuan di Jember) Diakses pada tanggal 12-02-2018

Banin Diar Sukmono. (2012). Eksploitasi Tubuh Perempuan di Televisi Sebagai Ironi Kepribadian Indonesia. Diakses pada tanggal 03-02-2018

Benedicta. (2015), Dinamika Otonomi Tubuh Perempuan: Antara Kuasa dan Negosiasi atas Tubuh, Diakses pada tanggal 03-022018

Bestiana, D. (2012). Citra Tubuh Dan Konsep Tubuh Ideal Mahasiswa Fisip Universitas Airlangga Surabaya (Doctoral Dissertation, Universitas Airlangga) Diakses pada tanggal 12-02-2018

Evan, D.S. \& P. (2004). Das Kapital untuk pemula. Jakarta : Resist Book

Fakih Mansoer. (2013), Analisis Gender Dan Trasformasi Social, Yogyakarta : Pustaka Pelajar

Handayani Ayu (2015). Eksploitasi Tubuh Perempuan Pada Sales Promotion Girl (Studi Kasus Komunikasi Non Verbal, Sales Promotion Girl, Produk Rokok). Skripsi di terbitkan. Universitas Kristen satya wacana.

Hidayat, T.W. (2016) Analisis Berita Kesehatan di Madia Massa Terhadap Pelayanan Publik. Jurnal Simbolika: Reseach and Learning in Communication Study, 1.2 Diakses pada tanggal 
12-02-2018

Ida, Rachmah. (2005). "Tubuh Perempuan dalam Goyang Dangdut." Jurnal Perempuan 41: Seksualitas. Jakarta: Yayasan Jurnal Perempuan.

Ikareski. (2017). Perilaku Sales Promotion Girl (SPG) Pada PT. Honda Makassar Indah Cabang Bone. Skripsi tidak diterbitkan. Makassar: Unismuh Makassar.

Lestari Afta Nur. (2012) : Eksploitasi Pada Perempuan Sales Promotion Girls 4 (2) : 139-147 Diakses pada tanggal 03-02-2018

Miles dan hubermas.1992. Analisis Data Kualitatif. Jakarta: UI-Pre

Mochtar. 2009. Tubuh Perempuan dalam Budaya Konsumen. Jakarta: FIB UI

Nawang Sasih, Tantri Dewi (2014) Persepsi Sales Promotion Girl (Spg) Terhadap Profesinya Dan Respon Spg Terhadap Persepsi Masyarakat. S1 Thesis, UAJY. Diakses pada tanggal 12-022018

Nursalam dkk.2016. Teori Sosiologi Klasik, Modern, Postmodern, Saintifik, Hermenuitik, Kritis, Evaluative Dan Integrative. Yogyakarta: Writing Revolution

Peter L. Berger, Tafsir Sosial Atas Kenyataan, pengantar oleh Frans M. Parera (Jakarta: LP3ES,1990) hal.17 Diakses pada tanggal 03-022018

Piliang, Yasraf Amir. 2003."Perempuan dan Mesin Hasrat Kapitalisme: Komodifikasi Perempuan dalam Program Hiburan Media Televisi" dalam Eksplorasi Gender di Ranah Jurnalisme dan Hiburan. LP3Y dan Ford Foundation.
Portal.makassar.go.id.makassarku.sejara h-kota-makassar diakses pada tanggal 10 juli 2018

Prabasmoro, Aquarini Priyatna.2006. Kajian Budaya Feminis: Tubuh, Sastra dan Budaya Pop. Yogyakarta dan Bandung: Jalasutra

Raditya Ardhie.2014.Sosiologi tubuh. Yogyakarta: Kaukaba dipantara

Rakhmat, Jalaluddin 1998. Phsikologi Komunikasi, cetakan ke-12. Bandung,.Remaja Rosdakarya

Ritzer George.2012, Teori Sosiologi dari Sosiologi Klasik Sampai Perkembangan Terakhir Postmodern, Yogyakarta : Pustaka Pelajar

Samsudin Virawati Nicke (2011). Eksploitasi Tubuh Sales Promotion Girl (Spg) Rokok 141156 Diakses pada tanggal 03-022018

Sarwono, Sarlito W. 2009. Pengantar Psikologi Umum. Jakarta : Rajawali Pers

Soekanto Soerjono. 2013, Sosiologi Suatu Pengantar. Jakarta: Rajawali Pers

Sugiyono, 2009, Metode Penelitian Kuantitatif, Kualitatif dan $R \& D$, Bandung : Alfabeta

Sukmono, B.D. (2015) Eksploitasi Tubuh Perempuan Di Televisi Sebagai Ironi Kepribadian Indonesia. Jurnal Komunikator, 4(01). Diakses pada tanggal 12-022018

Suranto, A. \& Subandi, A. (1998). Wanita yang menentang kodrat. Jakarta : Erlangga

Suyanto \& Narwoko. 2011. Sosiologi 
Teks Pengantar dan Terapan.

Jakarta: Kencana Prenada Media

Group

Syamsudin. (2006). Eksploitasi Wanita dalam Perspektif Kapitalis. Ejurnal Egalita. 1 (2): 20-40.

Thornham. (2010). Teori Feminis dan Cultur Studies. Yogyakarta: Jalasutra

Upe Ambo.(2010). Tradisi aliran dalam sosiologi dari filosofi positivistic ke post positivistic.Jakarta Rajawali pers

Wibowo.(2013), Perilaku dalam Organisasi. Jakarta: Rajawali Pers

Wolf, (2002). Mitos Kecantikan: Kala Kecantikan Menindas Perempuan. Yogyakarta: Niagara 